Jurnal

Kardiologi Indonesia

J Kardiol Indones. 2016;37:6-12

ISSN 0126/3773

Clinical Research

\title{
Apolipoproten B, LDL Cholesterol and apoB/apoA-I Ratio in Patients With Stable Angina
}

\author{
Oliivia Handayani, Djanggan Sargowo
}

' Department of Clinical Epidemiology, Division Julius Center for Health Sciences and Primary Care, University Medical Center Utrecht, the Netherlands, ${ }^{2}$ Department of Thoracic \& Cardiovascular Surgery, Heart and Diabetes Center, North Rhine Westphalia/University Hospital of Bochum, Bad Oeynhausen, Germany, ${ }^{3}$ Technology Assessment Unit, McGill University Health Center, Montréal, Canada, ${ }^{4} \mathrm{De}-$ partment Social Dentistry Academic Center for Dentistry Amsterdam, Amsterdam, the Netherlands
Aim: To acknowledge the nature of correlation between apolipoprotein $B$ concentrations and LDL cholesterol levels in patients with stable angina pectoris and also to show that the ratio of apoB/apoA-I may be a promising predictor for the risk of cardiovascular disease.

Methods: This is an observational study with cross-sectional approach of 34 patients with stable angina pectoris. Prior to the study, patients were advised to fast for $10-12$ hours and must complete the informed consent. Patients underwent physical examination and anthropometric measurements (height, body weight, waist circumference), blood test, and ECG check.

Results: From 34 patients, the prevalence of high levels of total cholesterol $(>200 \mathrm{mg} / \mathrm{dl})$ in men and women are $45.5 \%$ and $47.8 \%$, respectively; and $90.9 \%$ men and $87 \%$ women with increased LDL-C ( $\geq 100 \mathrm{mg} / \mathrm{dl})$. Low value of apoA-I was determined in 5 men $(45.5 \%)$ and 4 women $(17.4 \%)$; and high value of apoB was found in 7 men $(63.6 \%)$ and II women (47.8\%), whereas I 3 subjects with unfavorable apoB/apoA-I ratio. Six subjects had low levels of apoA-I along with high levels of apoB. ApoB/apoA-I ratio above 0.9 was found in 6 or 11 men $(54.5 \%)$ and 7 of 23 women $(30.4 \%)$.

Conclusion: We found that in 34 patients with stable angina, 18 of them $(52.9 \%)$ showed high plasma apoB concentration. This is parallel to 30 subjects $(88.2 \%)$ with high LDL cholesterol levels, and also I 3 subjects (38.2\%) with high apoB/apoA-I ratio. It can be concluded the higher the ratio of apoB to apoA-I, the greater the risk of cardiovascular disease. Lifestyle management and pharmacological intervention in dyslipidemia is important in reduction of cardiovascular events.

(J Kardiol Indones. 2016;37:6-12)

Keywords: Apolipoprotein B, dyslipidemia, apoB/apoA-I ratio, LDL cholesterol, cardiovascular risk 


\title{
Apolipoproten B, LDL Cholesterol and apoB/apoA-I Ratio in Patients With Stable Angina
}

\author{
Oliivia Handayani, Djanggan Sargowo
}

\begin{abstract}
Tujuan: Membuat model prognostik mortalitas 30-hari setelah transplantasi jantung.
Metode: Kami melaporkan pembuatan model prognostik mortalitas 30-hari setelah transplantasi jantung pada pasien dewasa. Analisis regresi logistik digunakan untuk membuat model menggunakan data 1,262 pasien dewasa yang menjalani transplantasi jantung. Akurasi model dinilai dari aspek kalibrasi (kesesuaian antara probabilitas yang diprediksi dengan mortalitas yang diobservasi) serta diskriminasi (kemapuan model untuk membedakan pasien dengan probabilitas kematian yang tinggi dan rendah dalam waktu 30 hari setelah transplantasi). Validitas internal dinilai menggunakan teknik bootstrapping.

Results: Usia dan jenis kelamin resipien, diagnosis pre-transplantasi, status transplantasi, waktu tunggu, durasi operasi bypass kardiopulmoner, usia dan jenis kelamin donor, serta ketidaksesuaian indeks masa tubuh dan golongan darah donor-resipien terpilih sebagai prediktor independen mortalitas 30-hari setelah transplantasi jantung. Model menunjukkan kalibrasi dan diskriminasi yang cukup baik (area di bawah the receiver operating characteristic curve adalah 0.71 ). Validitas internal model memadai. Untuk penggunaan dalam praktik sehari-hari, kami mentransformasi model logistik menjadi score chart.

Conclusion: Model prognostik mortalitas 30-hari setelah transplantasi jantung pada pasien dewasa ini memiliki akurasi dan validitas yang memadai. Model ini dapat membantu pengambilan keputusan melalui stratifikasi resipien berdasarkan probabilitas kematian setelah transplantasi dan memungkinkan alokasi donor transplantasi jantung secara lebih optimal.
\end{abstract}

(J Kardiol Indones. 2016;37:6-12)

Keywords: transplantasi jantung, mortalitas, risiko, scoring system, model prediksi

\section{Introduction}

A therogenic dyslipidemia (AD) is characterized by high plasma triglycerides, low high-density lipoprotein-cholesterol (HDL-C) and a high concentration of apolipoprotein (apo)

\footnotetext{
Alamat Korespondensi

Dr. Olivia Handayani, Program Pendidikan Dokter Spesialis-I Departemen Kardiologi dan Kedokteran Vaskular, Fakultas Kedokteran Universitas Brawijaya - RSUD Dr. Saiful Anwar, Malang. Tel. 08I I 379776. E-mail: HYPERLINK "mailto:oliviahandayani@ gmail.com"dan oliviahandayani@gmail.com
}

B-containing lipoproteins, particularly elevated small, dense LDL particles. The LDL particles in $\mathrm{AD}$ are smaller and denser, and have an increased atherogenic potential; small, dense HDL particles also occur. ${ }^{1}$

Effective diagnosis and management of atherogenic dyslipidemia requires an overall assessment for CVD risk, including age, presence of established CVD, hypertension or diabetes mellitus, family history of CVD and smoking. ${ }^{2}$ Emerging research has identified potential surrogate lipid markers for assessing cardiovascular risk, including apolipoprotein B (apoB), small dense LDL, LDL particle number, and nonhigh-density lipoprotein cholesterol (non-HDL-C). ${ }^{3}$ 
A recent review by Aguiar et $\mathrm{al}^{1}$ proposed that non$\mathrm{HDL}-\mathrm{C}$ was used to provide a better measure of CV risk than LDL-C levels.

A reduction in the concentration of non-HDL-C has been found to be a consistent marker of lower coronary heart disease risk on therapy. A meta-analysis of 14 statin trials, seven fibrate trials and seven trials of niacin monotherapy or combination therapy, showed a relationship between the percentage of nonHDL-C lowering and CVD risk reduction. Another study was done in 2001. The Lipid Research Clinics Program Follow-Up study was a primary prevention study of 4462 subjects aged 40-64 years, in whom mean baseline plasma triglycerides were $153 \mathrm{mg} / \mathrm{dl}$ in men and $117 \mathrm{mg} / \mathrm{dl}$ in women. The participants were followed for an average of 19 years. Non-HDL-C was found to be a strong predictor of all-cause mortality and CVD mortality than LDL-C. ${ }^{4}$ The concentration of non-HDL-C has been demonstrated to be highly correlated with that of apoB.

ApoB is a large amphipathic glycoprotein with 2 isoforms: apoB-100, which is synthesized in the hepatocytes, and apoB- 48 , a shortened version that is also derived from the apoB-100 gene and synthesized in the small intestine. ${ }^{5}$

In most conditions, more than $90 \%$ of all apoB in blood is found in LDL, and apoB does not occur on HDL particles. Thus, total apoB reflects the total number of potentially atherogenic particles. ${ }^{6}$

The ratio of apoB to apoA-I indicates the balance between atherogenic and anti-atherogenic particles, the higher the value, the higher the CV risk. ${ }^{6}$ Two largest trials, the AMORIS and the INTERHEART studies, show very strong direct relations between a high apoB/apoA-I ratio and an increased risk of fatal myocardial infarction (MI) and acute MI. ${ }^{7}$ Barter et $\mathrm{al}^{8}$ proposed that all lipid-lowering guidelines should recommend that the apoB/apoA-I ratio can be accepted as an alternative to TC/HDL-C ratio to calculate the lipoprotein-related risk of vascular disease; and target levels of apoB be adopted as alternatives to LDL or non-HDL cholesterol.

\section{Methods}

This is an observational study with cross-sectional approach that was carried out at one time point or over a short period to investigate the association of two variables in a given period of time.
We examined 34 patients with stable angina pectoris. Prior to the study, patients were advised to fast for 10-12 hours. Subjects must complete the informed consent as an agreeable action to participate in the study. Patients underwent physical examination and anthropometric measurements (height, body weight, waist circumference), blood test, and ECG check. We determined LDL-C, HDL-C and total cholesterol by homogenous assay; triglycerides by GPO-PAP method; whereas apoB and apoA-I by immunoturbidimetry. Non-HDL-C calculation was obtained by the formula of total cholesterol minus HDL-C.

Data was expressed in mean \pm standard deviation (SD). Parametric data was analyzed using student t-test, whilst nonparametric data was analyzed by chi square test. Variable analysis was conducted using ANOVA test, with IBM SPSS v22 software for Mac. A value of $\mathrm{P}<0.05$ was accepted as statistically significant.

\section{Results}

There were 34 individuals with stable angina pectoris remained to be analyzed in this study. Basic descriptive statistics by sex group of the sample are presented in Table 1.

Patient's mean age was $66 \pm 8.16$ years in men $(32.4 \%)$ and $59.4 \pm 10.70$ years in women $(67.6 \%)$. The traditional risk factors for stable angina pectoris include total cholesterol (TC), high-density lipoprotein (HDL) cholesterol, low-density lipoprotein (LDL) cholesterol, and triglycerides. The prevalence of high levels of total cholesterol $(>200 \mathrm{mg} / \mathrm{dl})$ in men and women are $45.5 \%$ and $47.8 \%$, respectively; and $90.9 \%$ men and $87 \%$ women with increased LDL-C $(\geq 100$ $\mathrm{mg} / \mathrm{dl})$. Hypertriglyceridemia was found mostly in women, 7 out of 23 subjects $(30.4 \%)$, whilst in men only 2 out of 11 subjects (18.2\%). NCEP ATP III recommends non-HDL-C as a secondary therapy target in patients with increased triglycerides, which in this study, the prevalence of non-HDL cholesterol in men and women were $81.8 \%$ and $78.3 \%$, respectively.

Further laboratory testing for cholesterol subfractions, include measurement of apolipoprotein (apo) $\mathrm{B}$ and apoA-I. The values of apoB and apoA-I varied from 66 to $101 \mathrm{mg} / \mathrm{dl}$ and from 122 to $166 \mathrm{mg} / \mathrm{dl}$, respectively. According to the health-related reference values of apolipoproteins, low value of apoA-I was determined in 5 men $(45.5 \%)$ and 4 women $(17.4 \%)$; and high value of apoB was found in 7 men $(63.6 \%)$ 
Table 1 Baseline characteristics of the sample $(\mathrm{N}=34)$

\begin{tabular}{lcc}
\hline & Men $(\mathrm{N}=11)$, mean $\pm \mathrm{SD}$ & Women $(\mathrm{N}=23)$, mean $\pm \mathrm{SD}$ \\
\hline Age, years & $66 \pm 8.16$ & $59.04 \pm 10.70$ \\
Total cholesterol (TC), mg/dl & $201.36 \pm 37.46$ & $209.61 \pm 52.94$ \\
Triglycerides, mg/dl & $115 \pm 45.69$ & $128.61 \pm 67.68$ \\
LDL-C, mg/dl & $143.27 \pm 36.29$ & $139.26 \pm 47.22$ \\
HDL-C, mg/dl & $48.64 \pm 10.38$ & $56.52 \pm 15.51$ \\
Non-HDL-C, mg/dl & $159.73 \pm 35.35$ & $162.96 \pm 53.66$ \\
TC/HDL ratio & $5.02 \pm 1.17$ & $4.74 \pm 1.61$ \\
LDL/HDL ratio & $3.03 \pm 0.84$ & $2.68 \pm 1.25$ \\
apoB, mg/dl & $111.18 \pm 27.14$ & $109.65 \pm 42.39$ \\
apoA-I, mg/dl & $134.36 \pm 24.9$ & $135.39 \pm 19.64$ \\
apoB/apoA-I ratio & $0.85 \pm 0.25$ & $0.84 \pm 0.36$ \\
Fasting glucose, mg/dl & $110.18 \pm 35.69$ & $109.13 \pm 77.18$ \\
HbA1c, \% & $6.50 \pm 1.45$ & $6.27 \pm 1.89$ \\
\hline
\end{tabular}

and 11 women (47.8\%), whereas 13 subjects with unfavorable apoB/apoA-I ratio. Six subjects had low levels of apoA-I along with high levels of apoB.

ApoB/apoA-I ratio above 0.9 was found in 6 of 11 men $(54.5 \%)$ and 7 of 23 women (30.4\%) (Figure 2).

Mean glycemic control, as reflected by current HbA1c (normal value 7.0\%, PERKENI Consensus 2011), was suboptimal at $6.34 \pm 1.73 \%$. However, 6 out of 34 unstable angina pectoris patients (17.65\%) had $\mathrm{HbA} 1 \mathrm{c}>7.0 \%$. Fasting glucose was increased in 4 men (36.4\%) and 5 women (21.7\%) (Figure 3).

\section{Discussion}

Cardiovascular disease (CVD) remains the leading cause of death worldwide. It is responsible for over 17.3 million deaths per year. Atherosclerosis is one of the major events that lead to development of CVD. Among the various factors of atherosclerosis, major risk factors are high cholesterol level, hypertension, metabolic syndrome and diabetes mellitus., ${ }^{9,10}$

Stable angina pectoris is part of cardiovascular disease that is characterized by discomfort in the

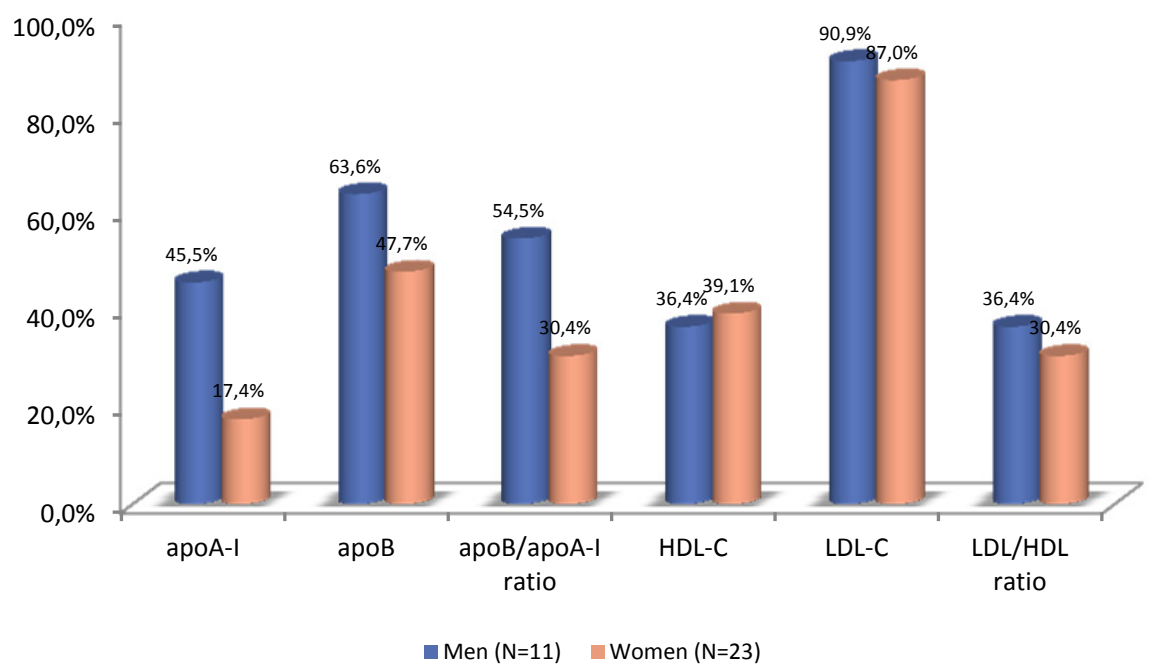

Figure 1. Lipid profiles 


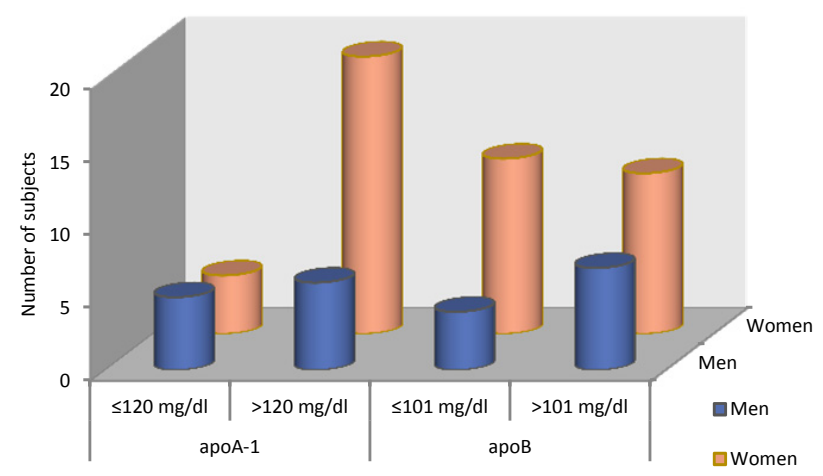

Figure 2. Distribution of subjects depending on the apoA-I and apoB levels

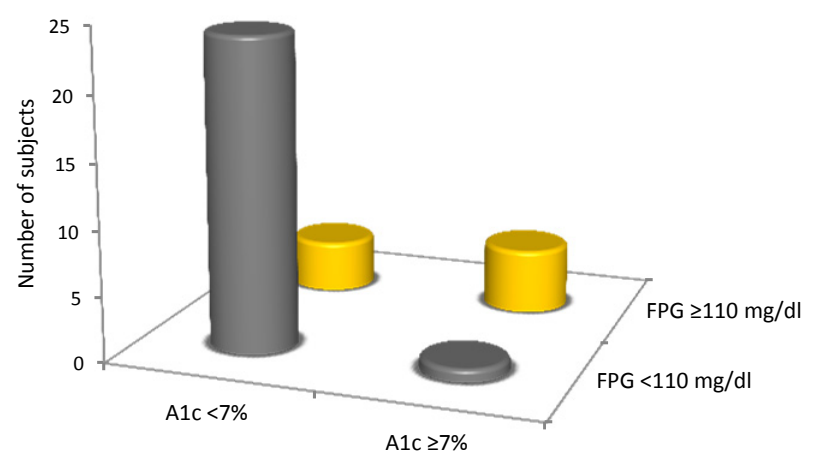

Figure 3. Distribution of subjects based on the fasting plasma glucose (FPG) concentration and HbA1c values

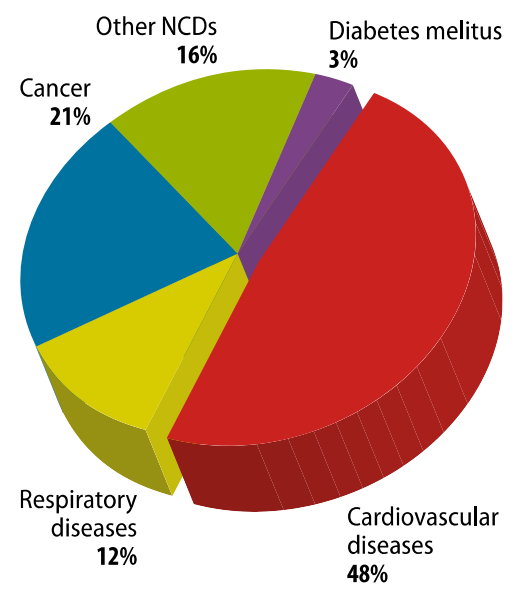

Figure 4 Distribution of global non-communicable disease by cause of death, both sexes ${ }^{9}$ chest, jaw, shoulder, back, or arms, typically elicited by exertion or emotional stress and relieved by rest or nitroglycerin. The prevalence of angina increases sharply with age in both sexes from $0.1-1 \%$ in women aged $45-54$ to $10-15 \%$ in women aged $65-75$ and from $2-5 \%$ in men aged $45-54$ to $10-20 \%$ in men aged $65-$ $74 .{ }^{11}$ In the study, subjects' mean age was $66 \pm 8.16$ years $(32.4 \%)$ in men and $59.4 \pm 10.70$ years $(67.6 \%)$ in women; therefore it corresponds to the reports of European countries.

Those clinical outcomes of coronary heart disease and other cardiovascular diseases are attributable to atherosclerosis, where there is an accumulation of immune cells and lipid droplets in the intima of arteries, which forms atherosclerotic plaques. Because low-density lipoprotein (LDL) is the major cholesterol carrier in humans, it is assumed that $\mathrm{LDL}$ is predominant contributor to plaque cholesterol. ${ }^{12,13}$

LDL cholesterols vary greatly in size, composition and structure, however, in general, they are comprised of spherical particles (22 $\mathrm{nm}$ in diameter) and surrounded by monolayer of phospholipids and unesterified cholesterol in which a single molecule of apoB is located. Modifications in the native LDL-C are capable of inducing aggregation and fusion of articles for the initiation of lipid accumulation in arterial intima. LDL particles can be modified by oxidation, glycation, nitration, carbamylation or other reactions to different degrees; however, the most studied modified LDL isoform is oxidized LDL (oxLDL). ${ }^{12}$

Our study revealed there were $90.9 \%$ men and $87 \%$ women with increased LDL-C $(\geq 100 \mathrm{mg} / \mathrm{dl})$, presumably high concentration of circulating oxLDL too. The serum concentration of oxLDL is known to be elevated in stable coronary artery disease and became even higher in acute coronary syndrome (ACS). ${ }^{14} \mathrm{~A}$ study by Wu et $\mathrm{al}^{15}$ in 500 patients with coronary heart disease $(\mathrm{CHD})$ stated that measuring oxLDL are difficult to obtain and commonly used in vitro measurements of oxLDL are time consuming and not practical for large studies; therefore it used antibody $4 \mathrm{E} 6$ to measure circulating oxLDL but it was not an independent overall predictor of CHD.

The toxic components of oxLDL may include aldehydes, oxysterols and lipid peroxidases. One of the best important changes during oxidation is the affinity of oxLDL to target cells. In the process of oxidation, the apoB in LDL changed, which led to the affinity of oxLDL to apoB receptors to decrease as the affinity 
to the scavenger receptors, such as CD36 (SR-B) and lectin-like oxidized low-density lipoprotein receptor-1 (LOX-1) increased. ${ }^{14}$

The present study has shown the close association of apolipoprotein with the development of atherosclerosis, and the apoB/apoA-I ratio becomes strong predictor of cardiovascular events, stable angina pectoris in particular, than other lipid parameters such as total cholesterol, LDL and HDL cholesterols.

Subjects with increase levels of LDL-C mostly correlate with increase of apoB concentrations. 18 subjects $(52.9 \%)$ had increase of both apoB concentrations and LDL-C levels. Since apoB provides a direct measure of the number of atherogenic lipoprotein particles in the circulation, it can be used to determine the $\mathrm{CV}$ risk in patients with atherogenic dyslipidemia. A total of $38.2 \%$ of subjects had the apoB/apoA-I ratio that exceeded 0.9; and all of them were overweight and obese. The epidemiological studies have also revealed that a higher apoB/apoA-I ratio indicates a higher cardiovascular risk. ${ }^{5,12,16}$

A study by Lu et $\mathrm{al}^{17}$ in 2011 presented that apoB and apoA-I were simple clinical indicators, and the apoB/apoA-I ratio was closely related with CVD, especially in overweight and obese patients. The apoB/ apoA-I ratio may provide some useful information in the differential diagnosis.

The high level of LDL-C and low level of HDL-C has been shown to be associated with an increased risk of CVD by many epidemiological studies. In this study, $35.3 \%$ subjects of stable angina pectoris have increase level of LDL-C and decrease of HDL-C level, whereas $52.9 \%$ of them only displayed increase LDL-C levels without HDL-C reduction. Our results are in accordance with the Framingham Heart study; that the incidence of coronary events among people with HDL-C below $40 \mathrm{mg} / \mathrm{dl}$ was twice high compared with other people. Even among subjects with LDL-C below $70 \mathrm{mg} / \mathrm{dl}$ or total cholesterol level below $200 \mathrm{mg} / \mathrm{dl}$, low HDL-C remains a significant high CVD risk. ${ }^{18}$

A meta-analysis of comparison of effectiveness of lowering apoB vs LDL-C and non-HDL-C in 2012 revealed that decrease in apoB concentration did not consistently improve risk prediction over improvement of LDL and HDL cholesterols. Nevertheless, it added information to predict coronary heart disease but not stroke or overall cardiovascular disease risk. ${ }^{19}$

The ratio of LDL to HDL cholesterol can also be used as a predictor of CV events. From data analysis, 11 subjects $(32.4 \%)$ were found to have increased
LDL/HDL ratio. Variation in the LDL/HDL ratio may be associated with alterations in metabolic indices, such as insulin resistance, poor glycemic control, and hypertension.

According to the study conducted in Chinese population by Ding et al, ${ }^{18} \mathrm{LDL}-\mathrm{C}$ remains as an effective and proper predictor for coronary artery disease prognosis, while LDL/HDL ratio can strengthen the prediction. Besides, high levels of apoB, apoB/apoA-I ratio, and low apoA-I level can increase the risk of CVD mortality among CAD patients.

Both apoB/apoA-I ratio and LDL/HDL ratio predict the risk of cardiovascular disease. However, in our patients with stable angina, the prevalence of increase apoB/apoA-I ratio is higher than the LDL/ HDL ratio $(38.2 \%$ vs. $23.5 \%)$. We propose that calculation of the LDL/HDL ratio may underestimate the risk in some patients compared with the use of apoB/apoA-I ratio, yet more studies are necessary to confirm its benefits as predictor of CVD.

Furthermore, the ratio of apoB to apoA-I may correlate with metabolic syndrome as we found $32.4 \%$ subjects with stable angina also have metabolic syndrome, and $63.6 \%$ of them presented with increase apoB/apoA-I ratio. Similarly, a previous study by Jing et $\mathrm{al}^{20}$ that included 1855 individuals with metabolic syndrome subjects and 6265 individuals without metabolic syndrome, demonstrated that apoB/ apoA-I ratio has a promising predictive effectiveness in detection of metabolic syndrome. This syndrome is closely linked to metabolic disorder such as insulin resistance and cardiovascular diseases.

Concentrations of apoB plasma may be superior to levels of LDL cholesterol as risk factors of coronary heart disease in patients with atherogenic dyslipidemia. The apoB/apoA-I ratio reflects the balance of cholesterol transport in a simple way. The higher the value of apoB/apoA-I ratio, the more cholesterol likely to be deposited in the arterial wall, thereby advancing atherogenesis and hence increasing $\mathrm{CV}$ risk. Further study with bigger sample is required to establish the role of apoB/apoA-I ratio as therapy target and predictor for cardiovascular disease.

\section{Conclusion}

We have investigated 34 patients with stable angina and 18 of them (52.9\%) showed high plasma apoB concentration. This is parallel to 30 subjects $(88.2 \%)$ 
with high LDL cholesterol levels, and also 13 subjects (38.2\%) with high apoB/apoA-I ratio. It can be concluded the higher the ratio of apoB to apoA-I, the greater the risk of cardiovascular disease.

Lifestyle management and pharmacological intervention in dyslipidemia is important in reduction of cardiovascular events.

\section{References}

1. Aguiar C, Alegria E, Bonadonna RC, Catapano AL, Consentino F, Elisaf M, Farnier M, Ferrières J, Filardi PP, Hancu N, Kayikcioglu M, Mello e Silva A, Millan J, Reiner Z, Tokgozoglu L, VAlensi P, Viigimaa M, Vrablik M, Zambon A, Zamorano JL, Ferrari R. A review of the evidence on reducing macrovascular risk in patients with atherogenic dyslipidemia: A report from an expert consensus meeting on the role of fenofibrate-statin combination therapy. Atheroclerosis 2015; 19(Suppl):1-12.

2. Chan DC, Barrett PHR, Watts GF. The metabolic and pharmacologic bases for treating atherogenic dyslipidemia. Best Pract Res Clin Endocrinol Metab 2014; 28:369-385.

3. Ramjee V, Sperling LS, Jacobson TA. Non-high-density lipoprotein cholesterol versus apolipoprotein B in cardiovascular risk stratification. J Am Coll Cardiol 2011; 58:457-463.

4. Orringer CE. Non-HDL cholesterol, apoB and LDL particle concentration in coronary heart disease risk prediction and treatment. Clin Lipidol 2013; 8:69-79.

5. Contois JH, McConnell, Sethi AA, Csako G, Devaraj S, Hoefner DM, Warnick GR. Apolipoprotein B and cardiovascular disease risk: Position statement from the AACC lipoproteins and vascular diseases division working group on best practices. Clin Chem 2009; 55:407-419.

6. Walldius G. The apoB/apoA-I ratio is a strong predictor of cardiovascular risk. In: Frank S, Kostner G. eds. Lipoproteins - Role in health and diseases. 2012. http://dx.doi.org/10.5772/47869

7. Walldius G, Jungner I. Rationale for using apolipoprotien B and apolipoprotein A-I as indicators of cardiac risk and as targets for lipid-lowering therapy. Eur Heart J 2005; 26:210-212.

8. Barter PJ, Ballantyne CM, Carmena R, Cabezas MC, Chapman JC, Couture P, De Graaf J, Durrington PN, Faergeman O, Frohlich J, Furberg CD, Gagne C, Haffner SM, Humphries SE, Jungner I, Krauss RM, Kwiterovich P, Marcovina S, Packard CJ, Pearson TA, Reddy KS, Rosenson R, Saffarzadegan N, Sniderman AD, Stalenhoef AF, Stein E, Talmud PJ, Tonkin AM, Walldius G, Williams KMS. ApoB versus cholesterol in estimating cardiovascular risk and in guiding therapy: Report of the thirty-person/ten country panel. J Internal Med 2006;
259:247-258.

9. World Health Organization. Global atlas on cardiovascular disease prevention and control. WHO, 2001.

10. Tamang HK, Timilsina U, Singh KP, Shrestha S, Raman RK, Panta P, Karna P, Khadka L, Dahal C. ApoB/apoA-I ratio is statistically a better predictor of cardiovascular disease (CVD) than conventional lipid profile: A study from Kathmandu Valley, Nepal. J Clin Diagnostic Res 2014; 8:34-36.

11. The Task Force on the management of stable angina pectoris of the European Society of Cardiology. Guidelines on the management of stable angina pectoris: Executive summary. Eur Heart J 2006; 27:1341-1381.

12. Faulin TES, Cavalcante MF, Abdalla DSP. Role of electronegative LDL and its associated antibodies in the pathogenesis of atherosclerosis. Clin Lipidol 2010; 5:719-719.

13. Jian X, Yang Z, Chandrakala AN, Pressley D, Parthasarathy S. Oxidized low density lipoproteins- Do we know enough about them? Cardiovasc Drugs Ther 2011; 25:367-377.

14. Yang H, Mohamed AA, Zhou S. Oxidized low density lipoprotein, stem cells, and atherosclerosis. Lipids Health Dis 2012; 11:85-93.

15. Wu T, Willett WC, Rifai N, Shai I, Manson JE, Rimm EB. Is plasma oxidized low-density lipoprotein, measured with the widely used antibody $4 \mathrm{E} 6$, an independent predictor of coronary heart disease among US men and women? J Am Coll Cardiol 2006; 48:973-979.

16. Kovanen PT, Jauhiainen M. Coronary heart disease prediction: Apolipoprotein B shows its might again - but still in vain? Eur J Preventive Cardiol 2015; 0:1-4.

17. Kaneva AM, Potolitsyna NN, Bojko ER, Odland JO. The apolipoprotein B/apolipoprotein A-I ratio as a potential marker of plasma atherogenicity. Disease Markers 2015: 1-7.

18. Lu M, Lu Q, Zhang Y, Tian G. ApoB/apoA-I is an effective predictor of coronary heart disease risk in overweight and obesity. J Biomed Res 2011; 25:266-273.

19. Ding D, Li X, Qiu J, Li R, Zhang Y, Su D, Li Z, Wang M, Lv X, Wang D, Yang Y, Xia M, Li D, Hu G, Ling W. Serum lipids, apolipoproteins and mortality among coronary artery disease patients. Biomed Res Int 2014: 1-11.

20. Robinson JG, Wang S, Jacobson TA. Meta-analysis of comparison of effectiveness of lowering apolipoprotein B versus lowdensity lipoprotein cholesterol and nonhigh-density lipoprotein cholesterol for cardiovascular risk reduction in randomized trials. Am J Cardiol 2012; 110:1468-1476.

21. Jing F, Mao Y, Guo J, Zhang Z, Li Y, Ye Z, DingY, Wang J, Jin $\mathrm{M}$, Chen K. The value of apolipoprotein B/apolipoprotein A1 ratio for metabolic syndrome diagnosis in a Chinese population: A cross-sectional study. Lipids in Health Dis 2014; 13:81-87. 